\title{
Seasonal organization of Siluriformes assemblages by their morpho- logical traits in the Arauca river floodplain, Venezuela
}

\author{
Gabriela Echevarría ${ }^{1, *}$, Jon Paul Rodríguez ${ }^{1,2}$ and Antonio Machado-Allison ${ }^{3}$ \\ ${ }^{1}$ Instituto Venezolano de Investigaciones Científicas, Centro de Ecología, Laboratorio de Biología de Organis- \\ mos. Carretera Panamericana, km 11, Altos de Pipe, Caracas 1020-A: apartado 21827. Miranda, Venezuela. \\ 2 International Union for the Conservation of Nature. Rue Mauverney 28, 1196 Gland, Switzerland. \\ 3 Instituto de Zoología y Ecología Tropical, Universidad Central de Venezuela, Los Chaguaramos, Caracas, \\ Venezuela. \\ * Corresponding author: hydropsichidae@gmail.com
}

Received: $11 / 07 / 18 \quad$ Accepted: 28/01/19

\begin{abstract}
Seasonal organization of Siluriformes assemblages by their morphological traits in the Arauca river floodplain, Venezuela

This study analyzed the functional organization of Siluriformes assemblages during one hydrological cycle in the floodplain of the Arauca River, in Venezuela, in relation to species morphologies. The study encompassed the stream La Piedra and the floodplain lake Arenosa. The functional organization of the assemblages was studied through the analysis of the Siluriformes species distributions within the morpho-space and the relation between morphological divergences and the coexistence patterns between species. The Siluriformes were more closely positioned than randomly expected within the morpho-space in the stream during August 2014 and in the lake during August 2015, whereas the morpho-space was smaller than expected in the lake during May 2015. Likewise, morphologically close species segregated spatially within the stream during July 2014, whereas they aggregated in the lake during August 2014. Altogether, these results suggest that the assembly of Siluriformes in the Arauca floodplain, as well as the strength of biotic and abiotic factors on the organization processes, can vary as a result of seasonal fluctuations in the water level and as a function of the habitat type.
\end{abstract}

Key words: Arauca River, functional traits, limiting similarity, morpho-space, stochastic processes

\section{RESUMEN}

Variación estacional en las asociaciones de Siluriformes en función de sus rasgos morfológicos en la planicie de inundación del río Arauca, Venezuela

Se analizó la organización funcional de asociaciones de Siluriformes durante un ciclo hidrológico en la planicie de inundación del rio Arauca, en Venezuela, en base a la morfología de las diferentes especies. El estudio abarcó el caño La Piedra y la laguna Arenosa. Estudiamos la organización de las asociaciones a través del análisis de la distribución de las especies de Siluriformes dentro del morfo-espacio y la relación entre las divergencias morfológicas y los patrones de coexistencia entre especies. Los Siluriformes estuvieron más agrupados de lo esperado al azar dentro del morfo- espacio en el caño durante agosto de 2014 y en la laguna durante agosto de 2015, mientras que en la laguna el morfo-espacio fue menor a lo esperado durante mayo de 2015. Igualmente, se observó una segregación espacial entre las especies morfológicamente similares dentro del caño en julio de 2014, mientras que en la laguna se observó una agregación significativa entre tales especies durante agosto de 2014. En general, estos resultados sugieren que la organización de los Siluriformes en la planicie de inundación del río Arauca, así como la intensidad de factores bióticos y abióticos sobre dichos procesos de organización, pueden variar como resultado de las fluctuaciones estacionales en el nivel del agua así como en función del tipo de hábitat.

Palabras clave: Río Arauca, rasgos funcionales, similaridad limite, morfo-espacio, procesos estocásticos 


\section{INTRODUCTION}

The unraveling of processes that originate biotic communities and maintain biodiversity is an important goal in ecology. Several assembly rules (MacArthur \& Levins, 1967; Diamond, 1975; Keddy, 1992) have been proposed and explored since the establishment of the species niche concept (Hutchinson, 1957) in order to explain the role of biotic and abiotic factors on species coexistence patterns at local scales: for example at a single lake (Keddy, 1992), or within a functional process zone (Thorp et al., 2008), such as a reach with a succession of riffles and pools. Other models, such as the habitat templet (Southwood, 1977; Townsend \& Hildrew, 1994) and the patch dynamics (Townsend, 1989) include the temporal dimension in the assembly of biotic communities, predicting patterns of community organization as a function of the intensity and frequency of disturbances. Alternately, Poff (1997) proposed a framework for the organization of biotic communities by their traits as a function of hierarchical environmental filters.

The study of community organization in tropical freshwater ecosystems represents a challenge because of their high spatial and temporal variability, as well as their great species diversity. Floodplains represent interesting systems for the study of fish community organization due to their temporal variation in environmental conditions that take place through highly predictable annual pulses (Junk et al., 1989). The interaction between temporal variation and environmental heterogeneity affects the structure of biotic communities in floodplains, as shown by different studies developed in Venezuela: for instance, in the floodplain of the Cinaruco River, the assembly of fish communities can change from random to nonrandom in short periods of time during rising waters (Arrington et al., 2005) and fish show high habitat selectivity during low waters (Arrington \& Winemiller, 2006); in the Apure River floodplain, fish mortality and survival rates vary drastically between hydrological seasons due to variations in habitat size and resources availability (Winemiller, 1989).

In recent years, the incorporation of functional traits has offered a fertile ground for the study of organization processes across different temporal and spatial scales. Morphological traits provide information about different aspects of fish function such as feeding mode and habitat use (Mouillot et al., 2006), conveying the ways species have responded to environmental and biotic pressures. The use of those morphological traits favors the study of effects of biotic and abiotic filters in the organization of communities under three models of community assembly: random assembly, environmental filtering and limiting similarity. The environmental filtering model sustains that environmental conditions act as filters that allow the colonization of sites by species with particular traits. Therefore, in extreme habitats, the species of a community have similar traits (Thienemann, 1918; Keddy, 1992). In contrast, the limiting similarity model assumes there are limits in the potential functional similarity of coexisting species, which impede the coexistence of species with very similar niches, generating spatial or temporal segregation them (MacArthur \& Levins, 1967; Abrams, 1983) in order to avoid interspecific competition. Under this model, biotic interactions determine the composition of communities at a local scale, favoring the coexistence of complementary species. The study of community functional organization has resulted in contrasting findings among different aquatic ecosystems. In coastal lagoons and estuaries, researches based on the analyses of morphological traits have evidenced that fish communities are organized predominantly according to environmental filters (Mouillot et al., 2006; Mouchet et al., 2013). In tropical floodplains there seems to be a predominance of limiting similarity patterns in the organization of fish communities (Winemiller, 1991; Montaña \& Winemiller, 2010). However, the evidence also suggests the importance of biotic and abiotic filters in freshwater ecosystems can vary seasonally. For example, in rapids of the Xingú River during high waters, fish communities seemed to be structured by environmental filters (Fitzgerald et al., 2017). On the contrary other fish communities have been reported to be structured by biotic interactions during low waters, both in tropical and temperate systems (Montaña et al., 2014).

The purpose of this research is to explore the 
functional organization of Siluriformes assemblages within a reach of the Arauca River floodplain, taking advantage of the environmental and morphological variabilities of the study system and taxonomic group, respectively. The floodplains of the Apure and Arauca rivers, in the Orinoco basin, exhibit a wide diversity of habitats that include secondary channels, lakes, ponds and swamps dominated by Mauritia flexuosa palms, that exhibit a high variety of water types with different $\mathrm{pH}$, conductivities and nutrients concentrations (Montoya et al., 2017). The seasonal variations in the water level and in the concentration of solutes and physical-chemical parameters are accompanied by changes in habitat use and trophic behavior of fishes (Montoya et al., 2017). Additionally, despite its high fish diversity and the presence of several species of commercial interest, the fish species and communities within this river remain little explored (Lasso et al., 2016). On the other hand, Siluriformes provide examples of extreme morphologies and of niche partitioning (Barbarino \& Winemiller, 2003; Lujan et al., 2011). Neotropical Siluriformes conform a species rich group, with 12 families present in the Orinoco drainage (Reis et al., 2016), which features varied life history strategies and adaptations (Bruton, 1996; Machado-Allison, 2005), for which they are an interesting model to explore the functional organization of fish communities. The morphological variability of this group is related to patterns in trophic position and habitat use, as shown in different Neotropical systems (Lasso et al., 1995; Lujan et al., 2011; Pagotto et al., 2011). For all these reasons, the Siluriformes assemblages within the floodplain of the Arauca River represent an appealing subject to explore patterns of community organization.

We analyzed the composition of Siluriformes assemblages and the morphological traits of the species present in two habitats with different conditions: a stream (lotic habitat) and a floodplain lake (lentic habitat) were chosen to explore potential differences in assemblage organization. We hypothesized that: 1) during high waters species of the assemblages of both the stream and the floodplain lake would be morphologically similar due to a homogenization in environmental conditions between the two habitats, resulting from their connection during high waters; 2) during low waters, the species would be less morphologically similar in the assemblage of the floodplain lake due to an increase in the effects of biotic filters associated to the reduction in habitat and food availability resulting from its isolation from the stream; and 3) there would be a significant spatial segregation between morphologically close species during the months of low waters within the floodplain lake, related to the conditions mentioned above.

\section{METHODS}

\section{Study area}

The study was conducted in a reach of the Arauca River floodplain drained by La Piedra stream, a secondary tributary channel of the Arauca, in the cattle ranch Hato Santa Luisa (Fig. 1A) from August 2014 to August 2015. Samples were taken from a $15 \mathrm{~km}$ segment of La Piedra stream $\left(7^{\circ} 40^{\prime}\right.$ $24.69^{\prime \prime} \mathrm{N}-67^{\circ} 29^{\prime} 41.09^{\prime \prime} \mathrm{W}$ ) and the 128 hectare floodplain lake Arenosa ( $7^{\circ} 41^{\prime} 10.38^{\prime \prime} \mathrm{N}-67^{\circ}$ $28,15.12^{\prime \prime} \mathrm{W}$ ). The area has annual average precipitation of $1475 \mathrm{~mm}$ and the peak of the rainy season takes place during July (Fig. 1B). In the lower Arauca River, the low waters season usually occurs between December and February, and the high waters season between July and October (Fig. 1B). The stream La Piedra has an average width of $45 \mathrm{~m}$ and a thin strip of riparian forest composed by arboreal species such as Cordia collococa, Coccoloba obtusifolia, Ouratea guildingii, the palm Bactris guineensis and shrubs such as Vinga luteola and Polygonum hydropiperoides. During the sampled period, the highest average water depths in La Piedra (3.8 m) were registered during August and the lowest (0.6 $\mathrm{m})$ between March and May. November and July corresponded to transitional phases of falling and rising waters, respectively (Fig. 1C). The Arenosa lake is highly connected to La Piedra stream during high waters and becomes isolated during low waters. The water depth in this lake can vary from an average $0.43 \mathrm{~m}$ in low waters to $2.73 \mathrm{~m}$ in high waters. Drastic seasonal variations in conductivity, $\mathrm{pH}$ and transparency were observed 

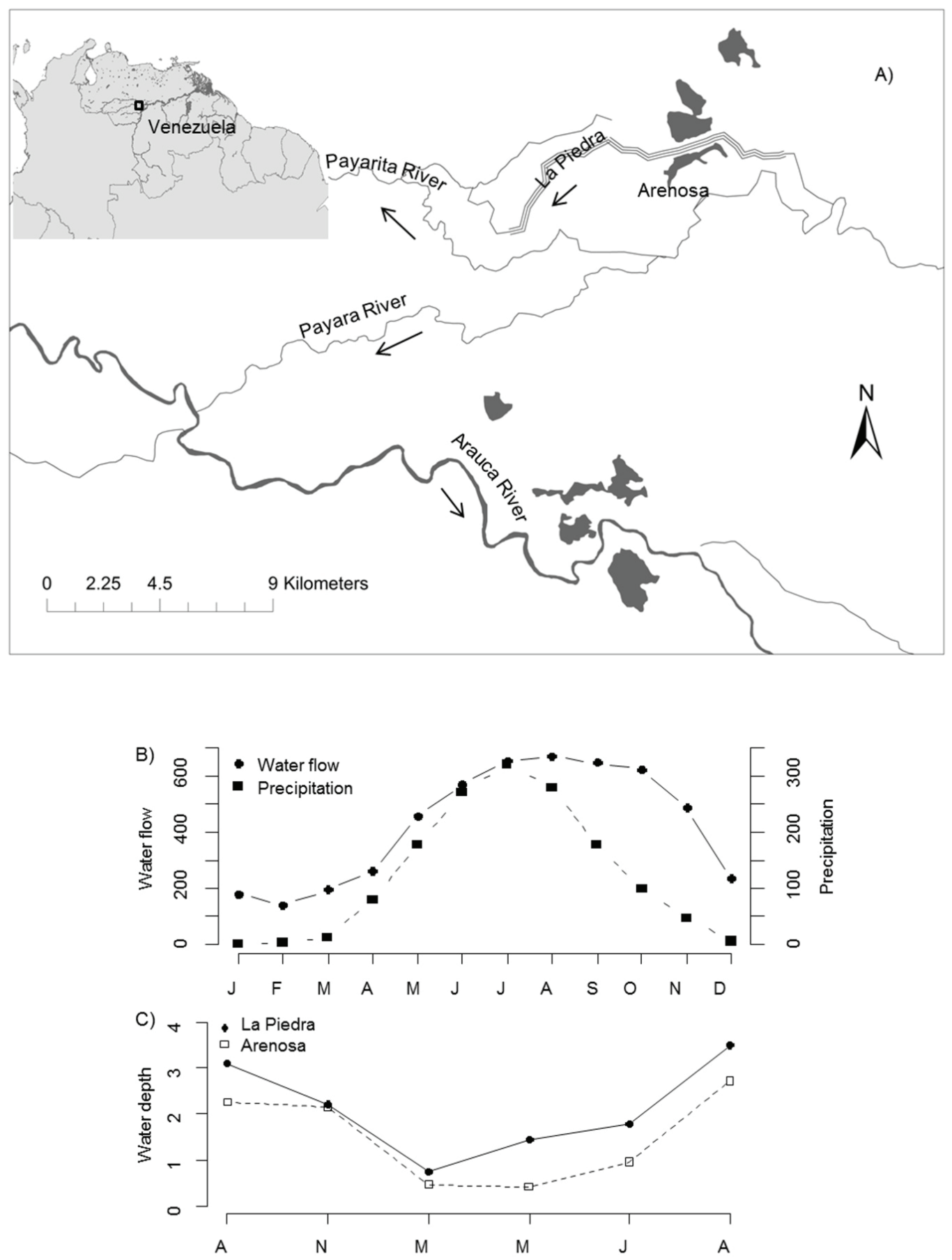

Figure 1. A) Location of the stream La Piedra (triple lines) and the floodplain lake Arenosa in the floodplain of the Arauca River and position of the study area in Venezuela. Black arrows indicate water flow direction. B) Monthly water flow values ( $\mathrm{m}^{3} / \mathrm{sec}$ ) in the Arauca River (Yagual station, source: Montoya et al., 2017) and monthly precipitation values (mm) in Hato Santa Luisa (based on data from 1694 to 2015) and C) Average water depth in La Piedra and Arenosa during the sampled months. A) Ubicación del caño La Piedra (segmento muestreado en líneas triples) y la laguna Arenosa en la planicie de inundación del río Arauca y posición del área de estudio en Venezuela. Las flechas negras indican la dirección del flujo de agua. B) Valores mensuales de flujo de agua ( $\mathrm{m} 3 / \mathrm{seg}$ ) en el río Arauca y valores mensuales de precipitación (mm) en el Hato Santa Luisa (basado en datos desde 1964 a 2015) y C) Profundidad promedio del agua en La Piedra y Arenosa durante los meses muestreados. 
in both water bodies during the studied period. In the stream, the $\mathrm{pH}$ ranged from 5.5 to 6.6 in the months of high waters and from from 6.3 to 8.9 during the months of low waters, the conductivity raised from 30.6 to $48.8 \mu \mathrm{S} / \mathrm{cm}$ in high waters to 88.4 to $88.8 \mu \mathrm{S} / \mathrm{cm}$ in low waters while the water transparency decreased from $50.0-58.0 \mathrm{~cm}$ in high waters to $35.4-39.3 \mathrm{~cm}$ in low waters (Echevarría et al., 2017). In the lake the $\mathrm{pH}$ ranged from 6.4 to 7.0 in high waters and from 5.6 to 6.0 in low waters, the conductivity increased notably from $33-49.2 \mu \mathrm{S} / \mathrm{cm}$ in high waters to $80.0-97.0 \mu \mathrm{S} / \mathrm{cm}$ during low waters, and the water transparency varied from 70.2 to $134.8 \mathrm{~cm}$ in high waters and decreased to 20.2 $22.8 \mathrm{~cm}$ in low waters (Echevarría et al., 2017).

\section{Sampling protocols}

Six sampling events took place in August and November 2014, and in March, May, July and August 2015. Fish samples were collected using 12 gill nets $2 \times 30 \mathrm{~m}$, eight of them with 114.3 $\mathrm{mm}$ (4.5") between knots, and four of them with $38.1 \mathrm{~mm}$ (1.5") between knots. During each month, each net was placed perpendicularly to the borders of the water bodies, with a distance of approximately $20 \mathrm{~m}$ between nets. Sampling sites were selected providing the water depth was above the two meters of the nets' depth, or, particularly during the months of low waters, where the water depth covered at least the $2 \mathrm{~m}$ of the of nets' depth. The nets were left immersed during approximately 20 hours in each water body. They were revised five times with intervals of four hours between collections in order to guarantee the independence of the samples. Thus, five collections were taken from each water body every month, each one consisting of all the catfish captured in the 12 nets during four hours. Each one of these collections was treated as an independent sample. All samplings were conducted between 5:00 to 22:00 $\mathrm{h}$.

The fishes were euthanized with a solution of $250 \mathrm{mg} / \mathrm{l}$ of tricaine methane sulfonate (MS-222), then fixed in formalin at $10 \%$ and transported to the Laboratory of Ichthyology of the Universidad Central de Venezuela. Eleven morphological measures were recorded to each Siluriformes specimen following Winemiller (1991). Traits were related to locomotion $(\mathrm{SL}=$ standard length, $\mathrm{BD}=$ body depth at the origin of the dorsal fin, $\mathrm{CPL}=$ caudal peduncle length, $\mathrm{CPD}=$ caudal peduncle depth), food acquisition ( $\mathrm{HW}=$ head width, $\mathrm{HL}=$ head length, $\mathrm{HD}=$ head depth, $\mathrm{ED}=$ eye diameter, $\mathrm{MW}=$ mouth width) and food assimilation ( $\mathrm{IL}=$ intestine length, $\mathrm{StL}=$ stomach length). All morphological traits except HW, ED and MW were standardized by dividing them against the SL. HW, ED and MW were divided by the HL. CPD was divided by CPL. Only adult specimens were measured, in order to avoid biases from ontogenetic development differences within species (Winemiller, 1991). Adulthood was determined based on the observed minimum size of sexual maturation, which was established as the state V of Nikolsky's categorization of sexual maturation of fishes (Nikolsky, 1963). Those specimens with missing parts due to piranha bites were not measured, but were recorded and included in the abundance data. All these traits, with the exception of SL were used in the statistical analyses. Voucher specimens of all the collected species of fish were deposited in the Ichthyologic Collection of the Museum of Biology of Universidad Central de Venezuela (MBUCV-V).

\section{Statistical analyses}

Trait values for each species resulted from averaging values obtained from all individuals of each species collected during the five sampled months in the two water bodies combined. In this research, we use functional space and morpho-space interchangeably to refer to the space encompassed by convex hulls obtained from PCAs carried out to perform the calculation of the functional indices. The multidimensional space of each PCA was considered a morpho-space.

The functional organization was measured using three indices: mean nearest neighbor distance (MNND), which estimates how close the species are within the functional space, the convex hull $(\mathrm{CH})$, which represents the volume of the functional niche (Villéger et al., 2008) or in this case the morpho-space (Winemiller, 1991) and the average distance to the centroid (DC), 
which estimates the position of the species in relation the centroid of the functional space (Laliberté et al., 2013). The functional indices were weighed by the species abundances, which were included in the calculations in the form of matrices of total abundances of each Siluriformes species per sample. All the indices were computed using matrices of Euclidean distances of species by their morphological traits obtained from PCA. The calculations were done with the packages picante (Kembel et al., 2015) and FD (Laliberté et al., 2013) in R (R Development Core Team, 2012). Comparisons of the indices among water bodies and seasons were carried out through Fligner tests. In order to test if the observed indices deviated from random, they were compared with simulated indices obtained from 999 simulated matrices under the independent swap null model (Gotelli, 2000), in which species occurrence frequencies and site species richness are maintained. Standard effect sizes were calculated for the four indices as: SES = (mean observed - mean simulated)/SD simulated. The simulations were carried out with the function RandomizeMatrix() of the package for $\mathrm{R}$ picante (Kembel et al., 2015).

Monthly species pairs' probabilities of co-occurrence within La Piedra and within Arenosa were calculated using the R package (R Development Core Team, 2012) cooccurr (Griffith et al., 2016) based on six monthly incidence matrices of each water body. Each monthly incidence matrix had five samples, represented by the five collections taken from each water body separately. Then, quantile regressions were calculated to explain the species probabilities of co-occurrence as a function of the species morphological divergences, expressed by the species' pairwise Euclidean distances, with the package quantreg (Koenker et al., 2015) in R. The quantile regression is an extension of the regression model of conditional means to the estimation of models for conditional quantile functions (Koenker \& Hallock, 2001). Slopes with their own intercepts are calculated for different proportions of the data encompassed by the quantiles. This method does not assume a normal distribution of errors, and it is recommended when the data show heterogeneous variances (Cade \& Noon, 2003). The 95th quantile was chosen in order to limit the effects of potential outliers (Mouchet et al., 2013). According to the framework proposed by Mouchet et al., (2013), positive co-occurrence - functional divergence associations take place under limiting similarity, since species with similar traits are likely to occupy the same niches and therefore segregate temporally or spatially at a local scale to be able to coexist regionally. On the contrary, negative associations between probabilities of co-occurrence and functional divergences take place under environmental filtering, because at a local scale, those species that can overpass the environmental filters are likely to share several traits and those with different traits tend to disappear from the communities (Mouillot et al., 2006).

\section{RESULTS}

The assemblages of Siluriformes were composed by 31 species, 30 observed in La Piedra stream and 24 species in the Arenosa floodplain lake, we collected 1546 Siluriformes specimens collected during the sampled period. Due to the presence of juveniles and specimens partially eaten by piranhas, the functional analyses were based on data of 23 species with abundances $\geq 5$, encompassing 502 specimens (Table 1). For detailed information about the species rarefaction curves of La Piedra and Arenosa and mean values of morphological traits see Echevarría et al. (2017).

The first two axes of the PCA ordination encompassed $86.0 \%$ of the morphological variation of the Siluriformes assemblages. The species of the family Loricariidae clearly separated from all other Siluriformes in the morpho-space (Fig. 2), being characterized by long and sometimes flat caudal peduncles, long intestines and short stomachs. The families Pimelodidae and Auchenipteridae partially overlapped in the functional space, featuring wide mouths and long stomachs. The species of Doradidae overlapped almost completely with Pimelodidae. These families, together with Hoplosternum littorale had deep bodies and caudal peduncles. Eye diameter and head width showed little variation among species. The traits that contributed most to the differentiation among species were the intestine length, the caudal peduncle depth and caudal peduncle length. 


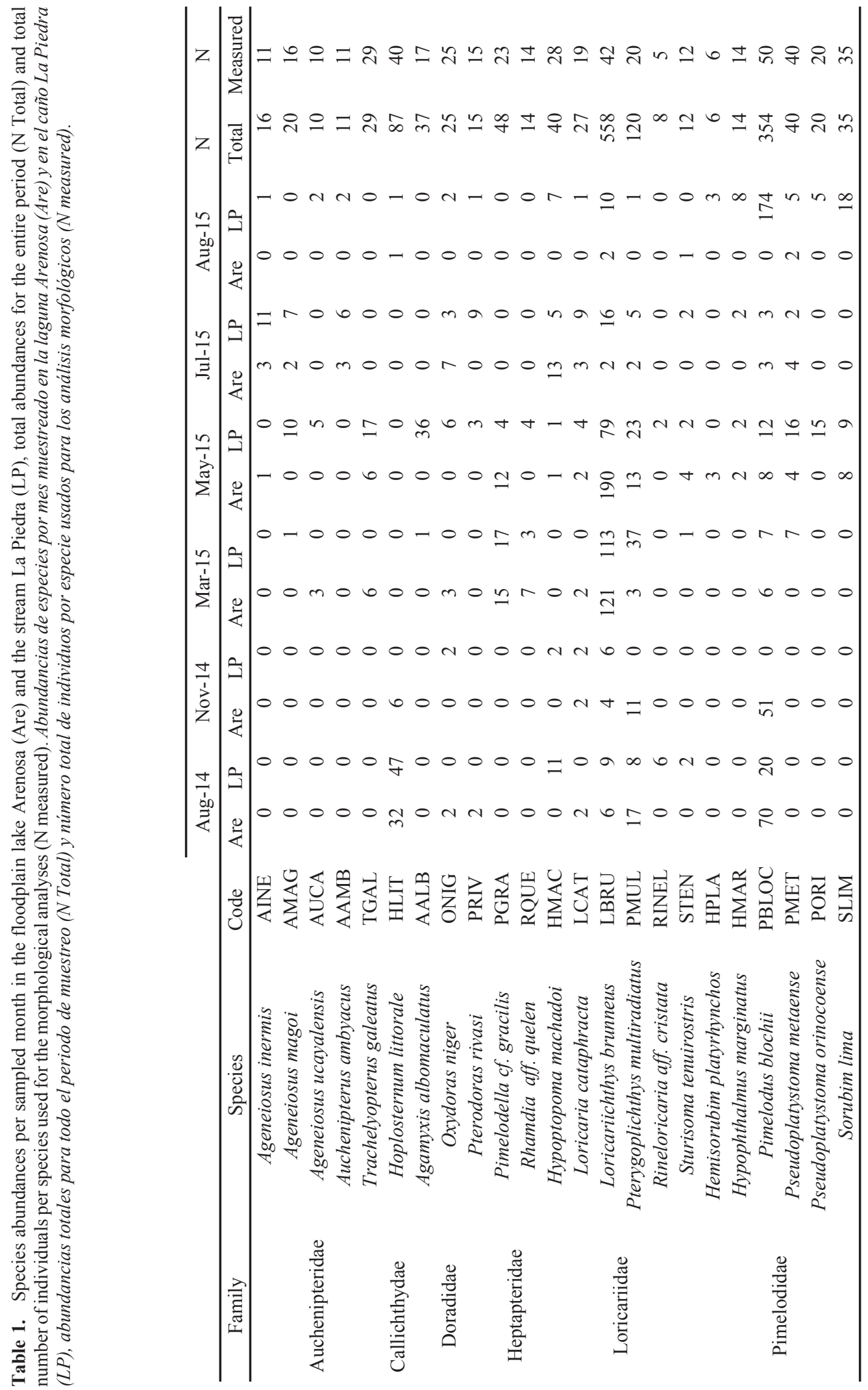




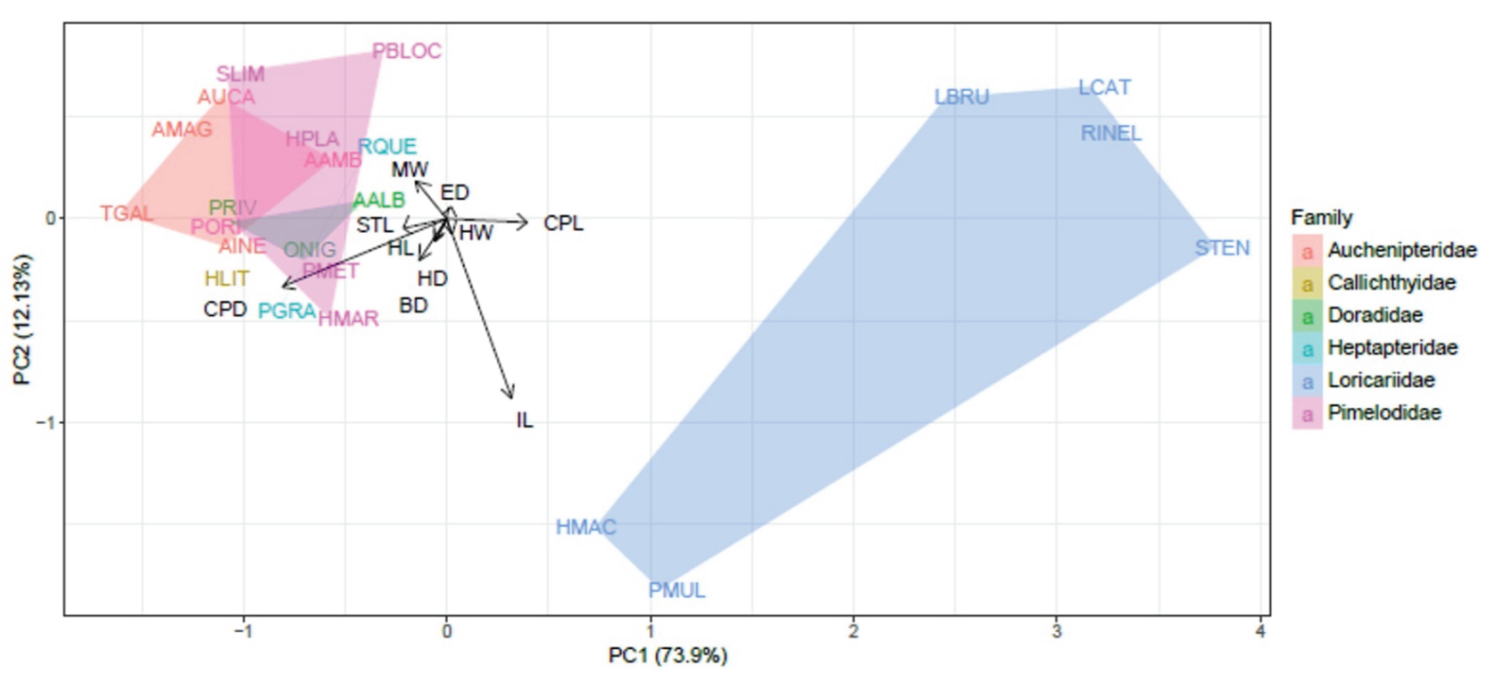

Figure 2. Principal component analysis ordination plot of the Siluriformes species by their morphological traits. Species codes in table 1. $\mathrm{MW}=$ mouth width, $\mathrm{ED}=$ eye diameter, $\mathrm{CPL}=$ caudal peduncle length, $\mathrm{HW}=$ head width, $\mathrm{IL}=$ intestine length, $\mathrm{BD}=$ body depth, $\mathrm{HD}=$ head depth, $\mathrm{HL}=$ head length, $\mathrm{CPD}=$ caudal peduncle depth, $\mathrm{STL}=$ stomach length. Gráfico de ordenación de análisis de componentes principales de las especies de Siluriformes en función a sus rasgos morfológicos. Códigos de las especies en tabla 1 . MW=ancho de la boca, ED= diámetro del ojo, $C P L=$ longitud del pedúnculo caudal, $H W=$ ancho de la cabeza, $I L=l o n g i t u d$ del intestino, $B D=$ profundidad del cuerpo, $H D=$ profundidad de la cabeza, $H L=$ longitud de la cabeza, $C P D=$ profundidad del pedúnculo caudal, $S T L=$ longitud del estómago.

There were not significant differences between La Piedra stream and the Arenosa lake in the mean nearest neighbor distances (MNND: W $=2.59, P=0.10$ ) or distances to the centroid (DC: $\mathrm{W}=1.58, P=0.21)$, but there were highly significance differences in convex hull volumes $(\mathrm{CH}: \mathrm{W}$ $=9.56, P=0.002)$, which tended to be higher in La Piedra stream. Within the Arenosa lake, the MNND was marginally different across seasons and showed high variances among samples during falling waters in November 2014 and rising waters in July 2015, but DC and CH did not show seasonal differences and had high variances across all months (Fig. 3). In La Piedra stream, the MNND and DC indices did not show seasonal differences, but the $\mathrm{CH}$ was marginally different among seasons. DC showed high variances in both habitats during most months.

The null model analyses showed a predominance of random colonization processes (Table 2 ), as indicated by a high incidence of random results across months in both habitats. According to the expectations of our first hypothesis, the Siluriformes tended to be closer than randomly expected in the morpho-space during high waters, but only in La Piedra stream. The indices did not show any significant pattern during low waters in Arenosa. The MNND was marginally lower than randomly expected in the Arenosa lake during August 2014 and significantly lower than expected during August 2015 in La Piedra stream (Table 2). The DC was not different from random in any of the water bodies and the $\mathrm{CH}$ was only significantly lower than expected within La Piedra stream during May 2015, indicating a reduced morpho-space during part of the low waters season.

The quantile regressions detected a significant relationship between morphological divergences and probabilities of co-occurrence of Siluriformes only during July 2015 in La Piedra stream (Table 3 ). The coefficient of the regression was negative, indicating environmental filtering. On the contrary, the only significant relationship between morphological divergences and probabilities of co-occurrence in the Arenosa lake took place during August 2014 and the coefficient was positive, indicating limiting similarity. Contrarily to the expectations of our third hypothesis, March and May, the months of 


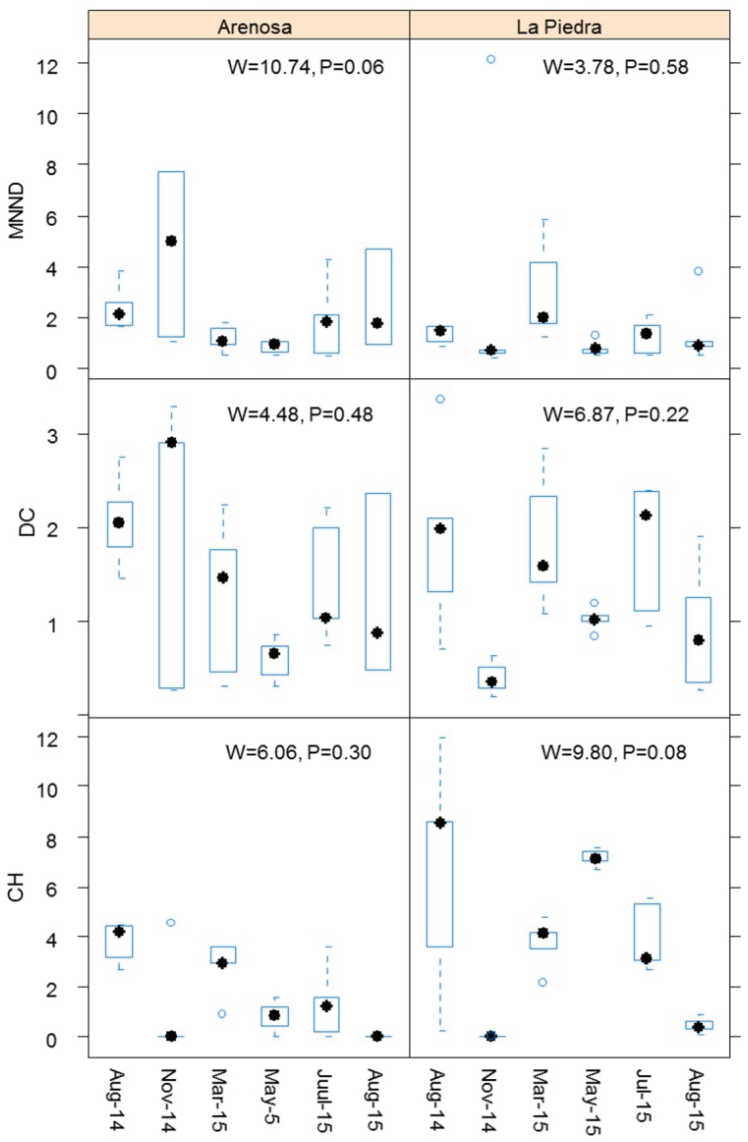

Figure 3. Boxplots of monthly MNND (mean nearest neighbor distance), DC (mean distance to centroid) and $\mathrm{CH}$ (convex hull volume) indices within the stream La Piedra and the floodplain lake Arenosa. W= coefficient of Fligner test of homogeneity of variances, $\mathrm{P}=$ test probability. Gráficos de caja de valores mensuales de los índices MNND (distancia promedio al vecino más cercano), DC (distancia promedio al centroide) y $\mathrm{CH}$ (volumen del polígono convexo) dentro del caño La Piedra y la laguna Arenosa. $W=$ coeficiente de la prueba de Fligner de homogeneidad de varianzas, $P=$ probabilidad de la prueba.

low waters, exhibited random associations between morphological divergences and species co-occurrences.

\section{DISCUSSION}

The functional organization of Siluriformes assemblages varied across months in La Piedra stream and the Arenosa floodplain lake. In the former, there were monthly variations in the size of the morpho-space, and in the latter there were seasonal differences in the mean distance among species within the morpho-space. Likewise, the functional organization of Siluriformes was different between La Piedra stream and the Arenosa lake. Most strikingly, the morpho-space was, in terms of the convex hull volume, larger in La Piedra stream. Besides, within both water bodies, the functional indices did not show similar patterns between August 2014 and August 215 . These results suggest high temporal variability in the functional structure of Siluriformes in the floodplain of the Arauca River at small temporal scales that seems to be related to variations in water level and to different environmental conditions and habitat sizes, for instance, lotic versus lentic conditions, differences in average water depth and the magnitude of water level variations between the stream and the floodplain lake.

The Siluriformes were more closely grouped in the morpho-space during high waters: in the floodplain lake during August 2014 and in the stream during August 2015, indicative of environmental filtering. Our results were not consistent with a greater influence of biotic factors in the assembly of fish communities during low waters observed in other tropical floodplains (Arrington \& Winemiller, 2006; Montaña \& Winemiller, 2010). Contrarily to what we expected, the morpho-space was significantly contracted during May within La Piedra stream, while within the Arenosa lake the species were closer to each other in the morpho-space during March and May, all of which suggest a dominance of environmental filters in the organization of Siluriformes during low waters. Such pattern might be related to decreased availability of habitats and trophic resources during the dry season (Winemiller, 1996; Scarabotti et al., 2011) and might have been the result of a dominance of Loricariichthys brunneus and Pterygoplichthys multiradiatus in both habitats during low waters, implying that the functional organization was determined mainly by the uniqueness of the morphological traits of Loricariidae.

In contrast, during high waters the morpho-spaces in both water bodies were determined by $H$. littorale and the Pimelodids Pimelo- 
Table 2. Results of the null model analyses. Observed values (Obs), means of simulations (Sim), probabilities (P) and standardized size effects (SES) of the functional indices per month by water body. MNND= mean nearest neighbor distance, $\mathrm{DC}=$ mean distance to the centroid, $\mathrm{CH}=$ convex hull volume. Resultados de los análisis de modelos nulos. Valores observados (Obs), promedios de las simulaciones (Sim), probabilidades (P) y tamaños estandarizados de efectos (SES) de los índices funcionales por mes por cuerpo de agua. $M N N D=$ distancia promedio al vecino más cercano, $D C=$ distancia promedio al centroide, $C H=$ volumen del polígono convexo.

\begin{tabular}{|c|c|c|c|c|c|c|c|c|}
\hline & \multicolumn{4}{|c|}{ Arenosa } & \multicolumn{4}{|c|}{ La Piedra } \\
\hline & \multicolumn{8}{|c|}{ MNND } \\
\hline Month & Obs & Sim & $\mathrm{P}$ & SES & Obs & Sim & $\mathrm{P}$ & SES \\
\hline Aug-14 & 0.54 & 1.02 & 0.09 & -1.01 & 0.93 & 0.95 & 0.57 & -0.05 \\
\hline Nov-14 & 1.45 & 1.49 & 0.61 & -0.04 & 0.78 & 1.29 & 0.25 & -0.68 \\
\hline Mar-15 & 0.33 & 0.47 & 0.11 & -0.93 & 1.27 & 0.64 & 0.99 & 2.54 \\
\hline May-15 & 0.38 & 0.38 & 0.63 & 0.01 & 0.53 & 0.50 & 0.64 & 0.28 \\
\hline Jul-15 & 1.00 & 0.89 & 0.69 & 0.28 & 0.53 & 0.67 & 0.31 & -0.64 \\
\hline \multirow[t]{2}{*}{ Aug-15 } & 1.54 & 1.71 & 0.53 & -0.14 & 0.39 & 0.63 & 0.04 & -1.22 \\
\hline & \multicolumn{8}{|c|}{$\mathrm{DC}$} \\
\hline Month & Obs & Sim & $\mathrm{P}$ & SES & Obs & Sim & $\mathrm{P}$ & SES \\
\hline Aug-14 & 1.55 & 1.63 & 0.85 & 1.18 & 1.90 & 1.80 & 0.58 & -0.08 \\
\hline Nov-14 & 1.61 & 1.29 & 0.95 & 1.94 & 1.06 & 1.87 & 0.26 & -0.79 \\
\hline Mar-15 & 0.53 & 1.02 & 0.48 & -0.39 & 1.97 & 1.57 & 0.63 & -0.08 \\
\hline May-15 & 0.80 & 0.97 & 0.60 & -0.06 & 1.56 & 1.99 & 0.31 & -0.63 \\
\hline Jul-15 & 2.01 & 2.02 & 0.22 & -0.86 & 1.40 & 2.09 & 0.48 & -0.22 \\
\hline \multirow[t]{2}{*}{ Aug-15 } & 1.42 & 1.89 & 0.58 & 0.26 & 0.92 & 1.02 & 0.66 & -0.02 \\
\hline & \multicolumn{8}{|c|}{$\mathrm{CH}$} \\
\hline Month & Obs & Sim & $\mathrm{P}$ & SES & Obs & Sim & $\mathrm{P}$ & SES \\
\hline Aug-14 & 0.99 & 1.30 & 0.48 & 1.30 & 0.10 & 0.10 & 0.41 & -0.45 \\
\hline Nov-14 & 0.22 & 0.41 & 0.42 & 0.42 & 0.00 & 0.01 & 0.51 & -0.35 \\
\hline Mar-15 & 1.82 & 1.87 & 0.43 & 1.87 & 0.09 & 0.14 & 0.47 & -0.36 \\
\hline May-15 & 2.63 & 2.70 & 0.84 & 2.70 & 0.51 & 0.74 & 0.03 & -2.00 \\
\hline Jul-15 & 0.83 & 1.46 & 0.74 & 1.87 & 1.19 & 0.38 & 0.44 & -0.27 \\
\hline Aug-15 & 0.54 & 0.17 & 0.50 & 1.17 & 0.22 & 0.58 & 0.14 & -1.06 \\
\hline
\end{tabular}

dus blochii, Sorubim lima and Hypophthalmus marginatus, which were the most abundant species during this season. Thus, the turnover of species with very different morphological traits can lead to similar patterns of functional organization across seasons. This turnover would be the result of the species responses to inter-seasonal flow variations and migration habits. For instance, migratory Pimelodids usually enter floodplains during high waters to exploit the higher offer of trophic resources (Röpke et al., 2015). These species possess high peduncles 
Table 3. Relationships between Siluriformes species pairs' morphological divergences (Euclidean distances) and probabilities of co-occurrence. 95th quantile regression coefficients (Coef Q95) and probabilities (P) per month by water body. Relaciones entre las divergencias morfológicas (distancias euclidianas) y las probabilidades de coexistencia de pares de especies de Siluriformes. Coeficientes de regresiones de cuartil $95^{\circ}$ (Coef $Q 95$ ) y probabilidades $(P)$ de las regresiones por mes por cuerpo de agua.

\begin{tabular}{ccc}
\hline & La Piedra & \\
Month & Coef Q95 & P \\
\hline August-14 & -2.60 & 0.33 \\
November & -0.02 & 0.39 \\
March & 2.00 & 0.57 \\
May & -0.06 & 0.93 \\
July & $\mathbf{- 0 . 1 9}$ & $\mathbf{0 . 0 1}$ \\
August-15 & -0.50 & 6.68 \\
\hline & Arenosa & \\
Month & Coef Q95 & P \\
August-14 & $\mathbf{0 . 5 8}$ & $\mathbf{0 . 0 1}$ \\
November & 0.97 & 0.45 \\
March & -1.02 & 0.17 \\
May & -1.57 & 0.68 \\
July & 0.33 & 0.22 \\
August-15 & 0.00 & 1.00 \\
\hline
\end{tabular}

associated to high movement capacity, on the contrary, Loricariids, which were present in the study area during the entire period, have slender caudal peduncles, that are considered as adaptations to highly variable conditions of water flow (Townsend \& Hildrew, 1994).

Nevertheless, there were indications of the influence of biotic filters in the Arenosa lake, but during August 2014, when Siluriformes assemblages organized according to a limiting similarity pattern. These results are interesting if we consider that the mean nearest neighbor distances were marginally smaller than randomly expected during that same month, suggesting fish communities could tend to segregate spatially when they are closely positioned in the morpho-space. Additionally, these results suggest biotic and environ- mental filters can act simultaneously, when environmental conditions are harsh but water level fluctuations are slow enough to facilitate biotic interactions to determine patch occupancy (Arrington et al., 2005).

However, environmental filters apparently were more frequently in action, particularly in La Piedra stream, as in other aquatic systems such as small streams (Peres-Neto, 2004), coastal zones (Mouillot et al., 2006) or estuaries (Mouchet et al., 2013), where environmental filtering seems to be the dominant pattern of community organization when morphological traits are considered. For instance, besides the reductions in morpho-space size during low waters or the species being closer in the morpho-space during high waters, morphologically close species showed higher probabilities of co-occurrence in La Piedra stream during July, which indicates the occupation of newly available patches during rising waters was driven by species sharing similar habitat requirements.

On the other hand, across the sampled period there was a prevalence of random associations of co-occurrences and morphological divergences, coupled with high variances of the functional indices and the frequent random results of the null model analyses, all of which highlights a dominance of stochastic colonization processes in the organization of Siluriformes assemblages. In La Piedra stream, random patterns were more frequent between high and falling waters, when the species richness and abundances of Siluriformes were relatively low, and fishes move intensely between habitats to forage and to avoid predation (Winemiller, 1996; Machado-Allison, 2005). In the floodplain lake, random patterns prevailed during those months when the species richness was low. Stochastic patterns can occur when the rate of disturbances, in this case water level variations, and the mobility of organisms among patches are very high (Townsend, 1989), which would explain the intermittent influence of biotic and abiotic filters in the organization of Siluriformes in the Arenosa lake. Such patterns suggests these assemblages are ruled by mobility control (Townsend, 1989), likely as a result of the strong environmental variation associated to its isolation from the stream during low waters, 
causing some species to disappear entirely from the floodplain lake for certain periods. Nevertheless, other forces might be acting simultaneously in the floodplain. Predation, for example, can be very strong during falling and low waters (Winemiller, 1996; Scarabotti et al., 2011).

In general terms, the functional organization of Siluriformes assemblages varied seasonally and locally, showing that the influence of biotic, environmental and stochastic factors on the organization of Siluriformes assemblages in the Arauca River floodplain can vary at fine spatial and temporal scales, and might be determined by the particular conditions of the different aquatic habitats within the floodplain. Additionally, the inter-annual differences in functional organization between the months of high waters hint that these variations could also take place at larger temporal scales. Hence, the need to carry out long term studies of fish community assembly in order to characterize broader patterns of organization. The results of our study, even though limited in its spatial scale, indicate the importance of the inclusion of the temporal dimension in the study of fish community assembly. Finally, the temporal heterogeneity in the Arauca River floodplain would propitiate frequent processes of extinction and colonization and as a result, the reshuffling of the assemblages of Siluriformes across hydrological seasons. At the same time, during these reshuffling events, other factors, biotic and abiotic, affect the organization of the Siluriformes assemblages. Human impacts such as damming, deforestation of riparian forests and overfishing might threaten the highly dynamic equilibrium of these assemblages.

\section{ACKNOWLEDGEMENTS}

INSOPESCA granted the scientific fish permits $N^{\circ} 404442$ and 455934. The authors wish to thank Dr. Carlos Rodríguez for his hospitality in Hato Santa Luisa and the staff of this ranch for their invaluable assistance in the field, particularly Erson Romero. The authors also would like to thank Angel Fernández for the identification of the species composing the riparian forest of La Piedra. The funds for this project were given by The Rufford Small Grant and Neotropical
Grassland Conservancy. Thanks also to Idea Wild for the donation of equipment necessary for the samplings.

\section{REFERENCES}

ABRAMS, P. 1983. The theory of limiting similarity. Annual Review of Ecology and Systematics, 14: 359-376. DOI: 10.1146/annurev.es. 14.110183 .002043

ARRINGTON, D. A., K. O. WINEMILLER \& C. A LAYMAN. 2005. Community assembly at the patch scale in a species rich tropical river. Oecologia, 144: 157-67. DOI: 10.1007/s00442-005-0014-7

ARRINGTON, D. A. \& K. O. WINEMILLER. 2006. Habitat affinity, the seasonal flood pulse, and community assembly in the littoral zone of a Neotropical floodplain river. Journal of the North American Benthological Society, 25: 126-141. DOI: 10.1899/08873593(2006)25[126:hatsfp]2.0.co;2

BARBARINO, A. \& K. O. WINEMILLER. 2003. Dietary segregation among large catfishes of the Apure and Arauca Rivers, Venezuela. Journal of Fish Biology, 63: 410-427. DOI: 10.1046/j.1095-8649.2003. 00163.x

BRUTON, M. N. 1996. Alternative life-history strategies of catfishes. Aquatic Living Resources, 9: 35-41. DOI: 10.1051/alr: 1996040

CADE, B. S. \& B. R. NOON. 2003. A gentle introduction to quantile regression for ecologists. Frontiers in Ecology and the Environment, 1: 412-420. DOI: 10.1890/1540-9295 (2003)001[0412:AGITQR]2.0.CO;2

DIAMOND, J. 1975. Assembly Rules. In: Ecology and Evolution of Communities. M. Cody \& J. Diamond, (ed.): 342-444. Harvard University Press, Cambridge, UK.

ECHEVARRÍA, G., J. P. RODRÍGUEZ \& A. MACHADO-ALLISON. 2017. Seasonal fluctuations in taxonomic and functional diversity in assemblages of catfishes in the Venezuelan Arauca River Floodplain. Studies on Neotropical Fauna and Environment, 53(1): 38-53. DOI: 10.1080/01650521.2017. 1387426 
FITZGERALD, D. B., K. O. WINEMILLER, M. H. SABAJ PÉREZ \& L. M. SOUSA. 2017. Seasonal changes in the assembly mechanisms structuring tropical fish communities. Ecology, 98: 21-31. DOI: 10.1002/ecy.1616

GOTELLI N. J. 2000. Null Model Analysis of Species Co-Occurrence Patterns. Ecology, 81: 2606-2621. DOI: 10.1890/0012-9658(2000) 081[2606:NMAOSC]2.0.CO;2

GRIFFITH, D. M., J. A. VEECH \& C. J. MARSH. 2016. cooccur: Probabilistic Species Co-Occurrence Analysis in R. Journal of Statistical Software, 69: 1-17. DOI: 10.18637/ jss.v069.c02

HUTCHINSON, E. 1957. Concluding remarks. Cold Spring Harb Symposium of Quantitative Biology. USA.

JUNK, W., P. BAYLEY \& E. SPARKS. 1989. The Flood Pulse Concept in River - Floodplain Systems. In: Proceedings of the International Large Rivers Simposium. P. Dodge (ed.): 110-127. Canadian Special Publications in Fish and Aquatic Science 106. Ontario, Canada.

KEDDY, P. 1992. Assembly and response rules: two goals for predictive community ecology. Journal of Vegetation Science, 3: 157-164. DOI: $10.2307 / 3235676$

KEMBEL, S. W., D. D. ACKERLY, S. P. BLOMBERG, W. K. CORNWELL, P. D. COWAN, M. R. HELMUS, H. MORLON \& O. CAMPBELL WEBB. 2015. Picante: R tools for integrating phylogenies and ecology. Bioinformatics, 26: 1463-1464. DOI: 10.1093/ bioinformatics/btq166

KOENKER, R. \& K. F. HALLOCK. 2001. Quantile Regression: An introduction. Journal of Economic Perspectives, 15.4: 43-56. DOI: $10.1234 / 12345678$

KOENKER, R., S. PORTNOY, P. NG, A. ZEILEIS, P. GROS, B. RIPLEY \& M. R. KOENKER. 2015. Quantreg: Quantile Regression. $\mathrm{R}$ package version 4.79. The Comprehensive R Archive Network, Vienna, Austria.

LALIBERTÉ, A. E., B. SHIPLEY \& M. E. LALIBERTÉ. 2013. FD: measuring functional diversity from multiple traits, and other tools for functional ecology. R package version 1.0. The Comprehensive $\mathrm{R}$ Archive Network, Vienna, Austria.

LASSO, C. A., C. SEÑARIS, O. LASSO-ALCALÁ \& J. CASTROVIEJO. 1995. Aspectos ecológicos de una comunidad de bagres (Pisces: Siluroidei) en los llanos inundables de Venezuela. Acta Biologica Venezueleica, 16: $1-31$.

LASSO, C. A., A. MACHADO-ALLISON \& D. C. TAPHORN. 2016. Fishes and aquatic habitats of the Orinoco River Basin: diversity and conservation. Journal of Fish Biology, 89: 174-191. DOI: 10.1111/jfb.13010

LUJAN, N. K., D. P. GERMAN \& K. O. WINEMILLER. 2011. Do wood-grazing fishes partition their niche?: morphological and isotopic evidence for trophic segregation in Neotropical Loricariidae. Functional Ecology, 25: 1327-1338. DOI: 10.1111/j.13652435.2011.01883.x

MACARTHUR, R. H. \& R. LEVINS. 1967. The limiting similarity, convergence and divergence of coexisting species. The American Naturalist, 101: 377-385.

MACHADO-ALLISON, A. 2005. Los Peces de Los Llanos de Venezuela: Un Ensayo sobre su Historia Natural. Segunda Ed. Consejo de Desarrollo Científico y Humanístico, Universidad Central de Venezuela. Caracas, Venezuela. MONTAÑA, C. G. \& K. O. WINEMILLER. 2010. Local-scale habitat influences morphological diversity of species assemblages of cichlid fishes in a tropical floodplain river. Ecology of Freshwater Fish, 19: 216-227. DOI: 10.1111/j.1600-0633.2010.00406.x

MONTAÑA, C. G., K. O. WINEMILLER \& A. SUTTON. 2014. Intercontinental comparison of fish ecomorphology: null model tests of community assembly at the patch scale in rivers. Ecological Monographs, 84(1): 91-107. DOI: 10.1890/13-0708.1

MONTOYA, J. V., A. OSÍO, M. C. PÉREZ \& V. PINEDA. 2017. Los ríos de los llanos de Apure. In: Ríos en riesgo de Venezuela. Volumen 1.D. Rodríguez-Olarte (ed): 75-107. Colección de Recursos Hidrobiológicos de Venezuela. Universidad Centro occidental Lisandro Alvarado (UCLA). Barquisimeto, Venezuela. 
MOUCHET, M. A., M. D. M. BURNS, A. M. GARCIA, J. P. VIEIRA \& D. MOUILLOT. 2013. Invariant scaling relationship between functional dissimilarity and co-occurrence in fish assemblages of the Patos Lagoon estuary (Brazil): Environmental filtering consistently overshadows competitive exclusion. Oikos, 122: 247-257. DOI: 10.1111/j.1600-0706. 2012.20411.x

MOUILLOT, D., O. DUMAY \& J. A. TOMASINI. 2006. Limiting similarity, niche filtering and functional diversity in coastal lagoon fish communities. Estuarine, Coastal and Shelf Science, 71: 443-456. DOI: 10.1016/j.ecss. 2006.08.022

NIKOLSKY, G. V. 1963. The Ecology of Fishes. Academic Press. London, UK.

PAGOTTO, J., E. GOULART, E. F. OLIVEIRA \& C. YAMAMURA. 2011. Trophic ecomorphology of Siluriformes (Pisces, Osteichthyes), from a tropical stream. Brazilian Journal of Biology, 71: 16 pp. DOI: 10.1590/S151969842011000300017

PERES-NETO, P. R. 2004. Patterns in the co-occurrence of fish species in streams: the role of site suitability, morphology and phylogeny versus species interactions. Oecologia, 140: 352-60. DOI: 10.1007/s00442-004-1578-3

POFF, N. 1997. Landscape filters and species traits: towards mechanistic understanding and prediction in stream ecology. Journal of the North American Benthological Society, 16: 391-409.

R DEVELOPMENT CORE TEAM. 2012. R: A language and environment for statistical computing. R Foundation for Statistical Computing. Vienna, Austria.

REIS, R. E., J. S. ALBERT, F. DI DARIO, M. M. M. MINCARONE, P. L. PETRY \& L. R. ROCHA. 2016. Fish Biodiversity and Conservation in South America. Journal of fish biology, 89: 12-47. DOI: 10.1111/jfb.13016

RÖPKE, C. P, S. A. AMADIO, K. O. WINEMILLER \& J. ZUANON. 2015. Seasonal dynamics of the fish assemblage in a flood- plain lake at the confluence of the Negro and Amazon Rivers. Journal of Fish Biology, 89(1): 194-212. DOI: 10.1111/jfb.12791

SCARABOTTI, P. A., J. A. LÓPEZ \& M. POUILLY. 2011. Flood pulse and the dynamics of fish assemblage structure from Neotropical floodplain lakes. Ecology of Freshwater Fish, 20: 605-618. DOI: 10.1111/j.1600-0633. 2011.00510.x

SOUTHWOOD, T. 1977. Habitat, the templet for ecological strategies? Journal of Animal Ecology, 46: 336-365.

THIENEMANN, A. 1918. Lebensgemeinschaft und Lebensraum. Naturwissenschaftliche Wochenschrift, 17: 282-290.

THORP, J., M. THOMS \& M. DELONG. 2008. The Riverine Ecosystem Synthesis. Elsevier. London, UK.

TOWNSEND, C. 1989. The patch dynamics concept of stream community ecology. Journal of the North American Benthological Society, 8: 36-50.

TOWNSEND, C. \& A. HILDREW. 1994. Species traits in relation to a habitat templet for river systems. Freshwater Biology, 31: $265-275$.

VILLÉGER, S., N. W. H. MASON \& D. MOUILLOT. 2008. New multidimensional functional diversity indices for a multifaceted framework in functional ecology. Ecology, 89: 290-301. DOI: 10.1890/07-1206.1

WINEMILLER, K. O. 1989. Patterns of variation in life history among South American fishes in seasonal environments. Oecologia, 81: 225-241.

WINEMILLER, K. O. 1991. Ecomorphological diversification in lowland freshwater fish assemblages from five biotic regions. Ecological Monographs, 61: 343-365. DOI: $10.2307 / 2937046$

WINEMILLER, K. O. 1996. Dynamic Diversity in Fish Assemblages of Tropical Rivers. In: Long-Term Studies of Vertebrate Communities. M. L. Cody and J. A. Smallwood (ed.): 99-134 Academic Press. London, UK.

Con el apoyo de:

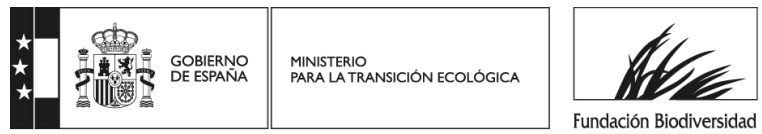

